\title{
Quality-of-life benefits and evidence of antitumour activity for patients with brain metastases treated with gefitinib
}

\author{
A Katz ${ }^{*, 1}$ and P Zalewski ${ }^{2}$ \\ 'Centro Paulista de Oncologia and Department of Oncology, Albert Einstein Hospital, São Paulo, Brazil; ${ }^{2}$ The Scarborough Hospital, Scarborough, Ontario, \\ Canada
}

\begin{abstract}
Brain metastases are a common complication of non-small-cell lung cancer (NSCLC). The role of chemotherapy in the treatment of brain metastases has not been clearly defined. Emerging case reports of patients with recurrent NSCLC treated as part of the Expanded Access Programme reveal that gefitinib ('Iressa', ZD 1839) has clinical activity in some patients with brain metastases. Here, we describe a number of case studies documenting the response of patients with brain metastases to treatment with gefitinib. Many of these patients had quality-of-life benefits with improvement of neurological and systemic symptoms; some had a partial response of their brain metastases and even complete responses have been seen in a few patients. One case report also describes a durable long-term response with concurrent treatment with gefitinib and radiotherapy. Such results call for larger trials designed to evaluate and define the role of gefitinib in the treatment of brain metastases in NSCLC patients, either as a single agent or in combination with radiation therapy.

British Journal of Cancer (2003) 89 (Suppl 2), SI5-SI8. doi:I0.1038/sj.bjc.660I478 www.bjcancer.com

(C) 2003 Cancer Research UK
\end{abstract}

Keywords: gefitinib ('Iressa', ZDI839); EGFR; quality of life; brain metastases; antitumour activity

Brain metastases are a common complication for patients with non-small-cell lung cancer (NSCLC) and a significant cause of morbidity and mortality. Radiotherapy remains the mainstay of treatment for brain metastases; however, patients treated with whole-brain radiation still have a poor prognosis with a median survival of only 3-4 months (Rodrigus et al, 2001). The role of chemotherapy in the treatment of patients with brain metastases has not been clearly defined. Many of these tumours are relatively resistant to chemotherapy and, traditionally, it has been assumed that the blood-brain barrier prevented chemotherapeutic agents from entering the central nervous system (CNS). However, the blood-brain barrier is disrupted in malignant brain tumours and recent evidence suggests that the chemosensitivity of the primary tumour is the major determinant of the response to systemic treatment of brain metastases, rather than the ability of the agent to penetrate an intact blood-brain barrier.

Gefitinib ('Iressa', ZD1839) is an orally active, epidermal growth factor receptor (EGFR) tyrosine kinase inhibitor that blocks signal transduction pathways implicated in the proliferation and survival of cancer cells. High levels of EGFR are frequently found in malignant primary brain tumours (Ekstrand et al, 1992) and in tumours that often metastasise to the CNS, such as NSCLC and breast cancer (Wikstrand et al, 1995). Large Phase II studies have recently shown that gefitinib has clinical activity in advanced NSCLC and is well tolerated (Fukuoka et al, 2003; Kris et al, 2003). A preclinical study in mice showed that gefitinib retains therapeutic activity on intracranial tumours despite the blood-

*Correspondence: A Katz, Av. Europa 105, São Paulo, Brazil;

E-mail: artkatz@uol.com.br brain barrier (Heimberger et al, 2002). Oral administration of gefitinib at 50 or $100 \mathrm{mg} \mathrm{kg}^{-1}$ day $^{-1}$ for 3 weeks in athymic mice with established intracerebral A431 human epidermoid carcinoma expressing EGFR increased median survival by $88 \%(P=0.009)$ and $105 \%(P<0.001)$, respectively. The preliminary results of a Phase II study also show modest activity of gefitinib in patients with recurrent glioblastoma (Peery et al, 2003).

Recently, a number of case reports of patients with recurrent NSCLC treated with gefitinib as part of the Expanded Access Programme (EAP) have described promising activity in patients with brain metastases. Here, we accumulate these results and discuss the possible implications and future directions.

\section{GEFITINIB IN PATIENTS WITH BRAIN METASTASES: RESULTS FROM THE EAP}

The case reports of patients with brain metastases secondary to NSCLC treated with gefitinib as part of the compassionate-use programme have recently been reported as published case studies (Cappuzzo et al, 2003a, b; Fujiwara et al, 2003; Knuti et al, 2003; Villano et al, 2003), at the World Conference on Lung Cancer 2003 (Chiu et al, 2003; Pino et al, 2003), at the American Society of Clinical Oncology 2003 conference (Ceresoli et al, 2003) and at the 'Iressa' Clinical Experience (ICE) meeting (Awada, ICE abs; Cappuzzo [a \& b], ICE abs; Dieriks, ICE abs; Stein, ICE abs; de la Cruz [a \& b], ICE abs; Maione, ICE abs; Martínez, ICE abs; DiazCantón, ICE abs; van der Kamp, ICE abs; van Zandwijk [b], ICE abs; Petruzelka [a], ICE abs; Azémar, ICE abs; Roggero, ICE abs; Kowalski, ICE abs; Martín-Algarra, ICE abs; Pavlakis, ICE abs). (See appendix for ICE abstracts). Together, these case reports 
Table I Published case series of patients with brain metastases and non-small-cell lung cancer treated with gefitinib as part of the Expanded Access Programme

\begin{tabular}{|c|c|c|c|}
\hline & Patients & Previous treatment & Results \\
\hline Pino et al (2003) & $\begin{array}{l}n=63 \text {, of whom II patients } \\
\text { had brain metastases }\end{array}$ & $\begin{array}{l}\text { One prior chemotherapy regimen: } 18 \\
\text { Two prior chemotherapy regimens: } 42\end{array}$ & $\begin{array}{l}\text { Of II patients with brain metastases, } \\
\text { two had a response in the brain }\end{array}$ \\
\hline Chiu et al (2003) & $n=57$, of whom 16 had brain metastases & $\begin{array}{l}\text { One prior chemotherapy regimen: I } \\
\geqslant 2 \text { prior chemotherapy regimens: } 15\end{array}$ & $\begin{array}{l}\text { Of } 16 \text { patients with brain metastases, } \\
\text { two had a partial response }\end{array}$ \\
\hline Ceresoli et al (2003) & $n=27$, all with brain metastases & $\begin{array}{l}\text { Platinum-based chemotherapy: } 20 \\
\text { Brain radiotherapy: II }\end{array}$ & $\begin{array}{l}\text { Two patients had a response in the brain, } \\
\text { one with complete remission } \\
\text { (both had brain radiotherapy }>3 \text { months } \\
\text { before starting gefitinib) }\end{array}$ \\
\hline Cappuzzo et al (2003a) & $n=4$, all with brain metastases & $\begin{array}{l}\geqslant 2 \text { prior chemotherapy regimens: } 4 \\
\text { Whole-brain radiotherapy: } 3\end{array}$ & $\begin{array}{l}\text { One patient had a complete response and three } \\
\text { patients had a partial response of brain metastases } \\
\text { Response duration: } 3+, 5,7,12+\text { months }\end{array}$ \\
\hline Cappuzzo et al (2003b) & $n=4$, all with brain metastases & $\begin{array}{l}\text { One prior chemotherapy regimen: } 2 \\
\geqslant 2 \text { prior chemotherapy regimens: } 2 \\
\text { Whole-brain radiotherapy: } 2\end{array}$ & $\begin{array}{l}\text { All four patients had a partial response of } \\
\text { brain metastases } \\
\text { Response duration: } 6+, 8,11+, 15 \text { months }\end{array}$ \\
\hline
\end{tabular}

suggest that gefitinib has activity in NSCLC brain metastases. The results of published case series are shown in Table 1 .

Most notable are the cases with a complete remission of brain metastases. In the largest case series that included 27 patients who had asymptomatic or symptomatic brain metastases, two of 20 evaluable patients had a response in the brain, with complete remission in one patient (Ceresoli et al, 2003). In another case series described in two separate publications by Cappuzzo et al, eight patients with NSCLC and brain metastases were treated with gefitinib (Cappuzzo et al, 2003a, b; [a \& b] ICE abs). One patient had a complete response and seven had partial responses in the brain, all within 3 months of treatment. The complete response in the brain was observed 6 weeks after treatment with gefitinib started in a patient who had completed whole-brain radiotherapy 3 months prior to the beginning of gefitinib (Figure 1). All eight patients experienced improvements in neurological and systemic symptoms.

Fujiwara et al (2003) described the case report of a patient who had achieved a complete response in the brain following treatment with gefitinib. This particular patient was diagnosed in July 1999 with stage IV adenocarcinoma of the left lung. In March 2001, after treatment with three different chemotherapy regimens, asymptomatic brain metastases were detected and subsequently treated with whole-brain radiotherapy. However, by October 2001 the patient's condition had deteriorated, with progressive brain metastases, and the patient was readmitted to hospital. Treatment with gefitinib started in November 2001 after which computed tomography scans showed that brain metastases had disappeared and that there was a marked regression of the lung tumour. The patient was then discharged in December 2001 and was able to resume full-time work for nearly 8 months. Two other published case reports also describe patients whose brain metastases responded to treatment (Knuti et al, 2003; Villano et al, 2003). In all three of these cases, patients had worsening neurological symptoms and deteriorating performance status before treatment with gefitinib. Following treatment, a significant clinical improvement was seen in all three patients: brain metastases disappeared in the patient already described and the sizes of the other two patients' lesions decreased. Quality of life was improved in all three patients.

One patient described at the ICE meeting showed good tolerance of concurrent gefitinib and radiotherapy (van Zandwijk [b], ICE abs, personal communication). In this case study, a 55-year-old male exsmoker with stage IV NSCLC and multiple pulmonary (lymphangitic) metastases developed multiple brain metastases

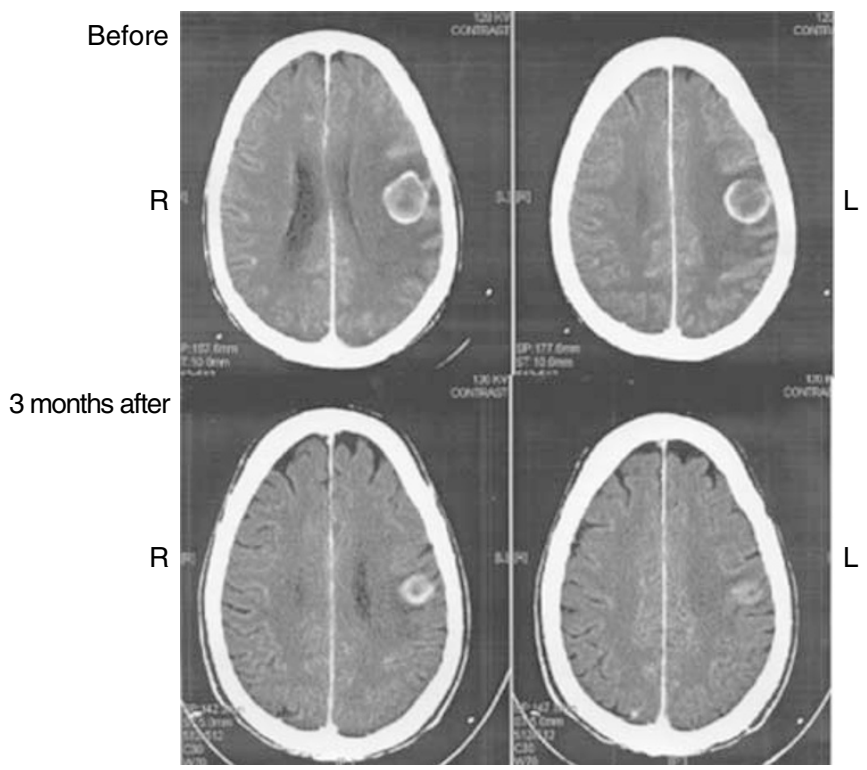

Figure I Computed tomography scan before and after treatment with gefitinib. Reproduced with permission from: Cappuzzo F, Calandri C, Bartolini S, Crino L (2003b).

(approximately 20 small lesions) after receiving treatment with gefitinib for $>1$ year (Figure 2). Radiotherapy to the brain $(10 \times 3 \mathrm{~Gy})$ and continued treatment with gefitinib resulted in disease stabilisation and symptom improvement and the patient was able to return to work. Delayed imaging 9 months later showed almost complete resolution of the brain metastases (Figure 3). Thus, although gefitinib did not prevent the development of brain metastases, concurrent treatment with radiotherapy and gefitinib resulted in a durable clinical response.

In total, 25 case reports of gefitinib use in patients with brain metastases and NSCLC were described at the ICE meeting (including the eight patients described by Cappuzzo et al) (Awada, ICE abs; Cappuzzo [a \& b], ICE abs; Dieriks, ICE abs; Stein, ICE abs; de la Cruz [a \& b], ICE abs; Maione, ICE abs; Martínez, ICE abs; Diaz-Cantón, ICE abs; van der Kamp, ICE abs; van Zandwijk [b], ICE abs; Petruzelka [a], ICE abs; Azémar, ICE abs; Roggero, 


\begin{tabular}{|ll|}
\hline OCTOBER 1999 & - A 55-year-old male exsmoker with stage IV non-small-cell lung cancer and multiple \\
pulmonary (lymphagitic) metastases, World Health Organization (WHO) performance status 1 \\
- No significant medical history
\end{tabular}

Figure 2 Case history of a patient with NSCLC and brain metastases taking gefitinib. Data previously presented by: van Zandwijk N. Risk/benefit of gefitinib ('Iressa', ZDI839). Oral presentation at the ICE meeting, Madrid, June 2003. Used with permission.

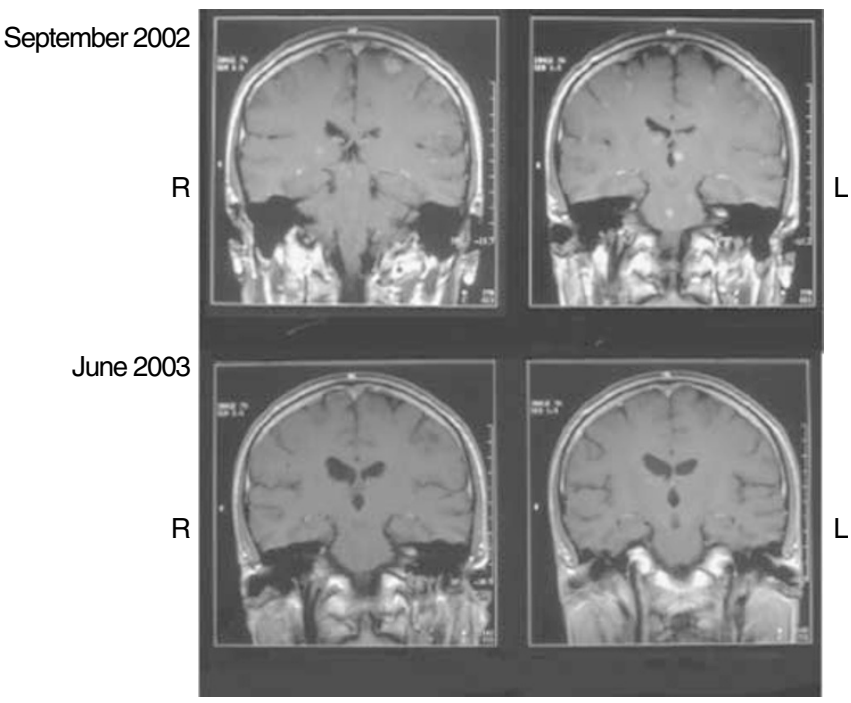

Figure 3 Computed tomography scan before and after treatment with gefitinib and radiotherapy (case history shown in Figure 2). Previously presented by: van Zandwijk N. Risk/benefit of gefitinib ('Iressa', ZD I839). Oral presentation at the ICE meeting, Madrid, June 2003. Reproduced with permission.

ICE abs; Kowalski, ICE abs; Martín-Algarra, ICE abs; Pavlakis, ICE abs). Of these, three patients had a complete response, 10 a partial response, eight had stable disease and four patients had progression of their brain metastases. In all of these case reports, treatment with gefitinib appears to have been well tolerated. Any reported adverse events are consistent with the adverse-event profile of gefitinib established in Phase II trials in patients with advanced NSCLC (Fukuoka et al, 2003; Kris et al, 2003). There was also no unexpected or cumulative toxicity described for the patient who received concurrent gefitinib and radiotherapy (van Zandwijk [b], ICE abs).

\section{DISCUSSION}

A number of case reports suggest that gefitinib has clinical activity against brain metastases of patients with NSCLC. These preliminary data indicate that patients with brain metastases should not be excluded from treatment with gefitinib (as they were in some of the early clinical trials of gefitinib), an opinion also expressed by Cappuzzo et al (2003b). There is a need for larger trials to followup these positive preliminary findings in the hope of developing a treatment option for these patients who have a very poor prognosis. Combination of radiotherapy and gefitinib administered either concurrently or sequentially warrants further investigation.

A consideration for such future studies in patients with brain metastases is the optimum dose of gefitinib if dexamethasone is also being administered. Dexamethasone is an inducer of cytochrome P450 3A isoenzymes, including CYP 3A4, which has been identified as the isoenzyme primarily involved in the metabolism of gefitinib. Therefore, coadministration of dexamethasone may lead to increased metabolism of gefitinib, with consequently lower plasma concentrations and potentially reduced efficacy. In addition, such studies would need to use standardised patient staging to identify and monitor asymptomatic as well as symptomatic brain metastases.

A number of preclinical studies support the combined use of radiotherapy and gefitinib as a strategy for cancer treatment (Bianco et al, 2002; Huang et al, 2002; Magne et al, 2002; Williams et al, 2002; Solomon et al, 2003). Coadministration of gefitinib potentiated the antitumour effect of radiation on A431 cells 
(human vulvar squamous-cell carcinoma cells that express high levels of EGFR) both in vitro and in vivo (Solomon et al, 2003). Another preclinical study showed a cooperative antiproliferative effect when gefitinib was combined with radiation in colon, ovarian, NSCLC and breast cancer cell lines (Bianco et al, 2002). Further, the combination of gefitinib and radiation resulted in long-term tumour growth regressions of established human colon cancer GEO and lung adenocarcinoma A549 xenografts (Bianco

\section{REFERENCES}

Bianco C, Tortora G, Bianco R, Caputo R, Veneziani BM, Caputo R, Damiano V, Troiani T, Fontanini G, Raben D, Pepe S, Bianco AR, Ciardiello F (2002) Enhancement of antitumor activity of ionizing radiation by combined treatment with the selective epidermal growth factor-tyrosine kinase inhibitor ZD1839 ('Iressa'). Clin Cancer Res 8: $3250-3258$

Cappuzzo F, Ardizzoni A, Soto-Parra H, Gridelli C, Maione P, Tiseo M, Calandri C, Bartolini S, Santoro A, Crino L (2003a) Epidermal growth factor receptor targeted therapy by ZD 1839 ('Iressa') in patients with brain metastases from non-small cell lung cancer (NSCLC). Lung Cancer 41: $227-231$

Cappuzzo F, Calandri C, Bartolini S, Crino L (2003b) ZD 1839 in patients with brain metastases from non-small-cell lung cancer (NSCLC): report of four cases. Br J Cancer 89: 246-247

Ceresoli GL, Gregorc V, Cappuzzo F, Spreafico A, Bencardino KB, Lombardo L, Schipani S, Cozzarini C, Crino L, Villa E (2003) ZD1839 in non-small cell lung cancer (NSCLC) patients with brain metastases (BM). Proc Am Soc Clin Oncol 22: 674 (abs 2709)

Chiu C-H, Tsai C-M, Chiang S-C, Chen Y-M, Perng R-P (2003) Effect of ZD1839 ('Iressa') on metastatic brain lesions in patients with advanced non-small cell lung cancer. Lung Cancer 41(Suppl 2): 251 (abs P-631)

Ekstrand AJ, Sugawa N, James CD, Collins VP (1992) Amplified and rearranged epidermal growth factor receptor genes in human glioblastoma reveal deletions of sequences encoding portions of the $\mathrm{N}$ - and/or C-terminal tails. Proc Natl Acad Sci USA 89: 4309-4313

Fujiwara K, Kiura K, Ueoka H, Tabata M, Hamasaki S, Tanimoto M (2003) Dramatic effect of ZD1839 ('Iressa') in a patient with advanced non-small-cell lung cancer and poor performance status. Lung Cancer 40: $73-76$

Fukuoka M, Yano S, Giaccone G, Tamura T, Nakagawa K, Douillard J-Y, Nishiwaki Y, Vansteenkiste J, Kudoh S, Rischin D, Eek R, Horai T, Noda K, Takata I, Smit E, Averbuch S, Macleod A, Feyereislova A, Dong R-P, Baselga J (2003) Multi-institutional randomized phase II trial of gefitinib for previously treated patients with advanced non-small-cell lung cancer. J Clin Oncol 21: 2237-2246

Heimberger AB, Learn CA, Archer GE, McLendon RE, Chewning TA, Tuck FL, Pracyk JB, Friedman AH, Friedman HS, Bigner DD, Sampson JH (2002) Brain tumors in mice are susceptible to blockade of epidermal growth factor receptor (EGFR) with the oral, specific, EGFR-tyrosine kinase inhibitor ZD1839 ('Iressa'). Clin Cancer Res 8: $3496-3502$

Huang SM, Li J, Armstrong EA, Harari PM (2002) Modulation of radiation response and tumor-induced angiogenesis after epidermal growth factor receptor inhibition by ZD1839 ('Iressa'). Cancer Res 62: 4300-4306 et al, 2002). Radiotherapy treatment may also disrupt the bloodbrain barrier (van Vulpen et al, 2002) that would allow improved access of gefitinib to brain tumour tissue.

In summary, a number of case reports suggest activity of gefitinib against brain metastases secondary to advanced NSCLC. Larger trials are needed to validate these findings and further investigate the potential of combined gefitinib and radiotherapy treatment.

Knuti KA, Wharton RH, Wharton KL, Chabner BA, Lynch Jr TJ, Penson RT (2003) Living as a cancer surpriser: a doctor tells his story. Oncologist 8: $108-122$

Kris MG, Natale RB, Herbst RS, Lynch Jr TJ, Prager D, Belini CP, Schiller JH, Kelly K, Spiridonidis H, Sandler A, Cella D, Wolf MK, Averbuch SD, Ochs JJ, Kay AC (2003) Efficacy and safety of gefitinib ('Iressa', ZD1839), an inhibitor of the epidermal growth factor receptor tyrosine kinase, in symptomatic patients with advanced non-small cell lung cancer. A randomized trial. JAMA 22: 2149-2158

Magne N, Fischel JL, Dubreuil A, Formento P, Marcie S, Lagrange J-L, Milano G (2002) Sequence-dependent effects of ZD1839 ('Iressa') in combination with cytotoxic treatment in human head and neck cancer. Br J Cancer 86: 819-827

Peery TS, Reardon DA, Quinn J, Ochs J, Wikstrand CJ, Stenzel TT, Bigner DD, Friedman HS, Rich JN, Dancey J (2003) Phase II trial of ZD1839 for patients with first relapse glioblastoma. Proc Am Soc Clin Oncol 22: 99 (abs 396)

Pino MS, Gelibter A, Ceribelli A, Milella M, Pollera CF, Moscetti L, Di Cocco B, Salesi N, Cognetti F (2003) Results from compassionate use of gefitinib ('Iressa') in progressive pretreated non small cell lung cancer (NSCLC): our experience. Lung Cancer 41(Suppl 2): 250 (abs P-627)

Rodrigus P, de Brouwer P, Raaymakers E (2001) Brain metastases and nonsmall cell lung cancer. Prognostic factors and correlation with survival after irradiation. Lung Cancer 32: 129-136

Solomon B, Hagekyriakou J, Trivett MK, Stacker SA, McArthur GA, Cullinane C (2003) EGFR blockade with ZD1839 ('Iressa') potentiates the antitumor effects of single and multiple fractions of ionizing radiation in human A431 squamous cell carcinoma. Int J Radiat Oncol Biol Phys 55: $713-723$

van Vulpen M, Kal HB, Taphoorn MJB, El Sharouni SY (2002) Changes in blood-brain barrier permeability induced by radiotherapy: implications for timing of chemotherapy? Oncol Rep 9: 683-688 (review)

Villano JL, Mauer AM, Vokes EE (2003) A case study documenting the anticancer activity of ZD1839 ('Iressa') in the brain. Ann Oncol 14: $656-658$

Wikstrand CJ, Hale LP, Batra SK, Hill ML, Humphrey PA, Kurpad SN, McLendon RE, Moscatello D, Pegram CN, Reist CJ, Traweek ST, Wong AJ, Zalutsky MR, Bigner DD (1995) Monoclonal antibodies against EGFRvIII are tumor specific and react with breast and lung carcinomas and malignant gliomas. Cancer Res 55: 3140-3148

Williams KJ, Telfer BA, Stratford IJ, Wedge SR (2002) ZD1839 ('Iressa'), a specific oral epidermal growth factor receptor-tyrosine kinase inhibitor, potentiates radiotherapy in a human colorectal cancer xenograft model. Br J Cancer 86: 1157-1161 